\title{
Analisis Kemampuan Calon Guru Matematika dalam Pengajuan Masalah Ditinjau dari Gaya Kognitif Field Independent dan Field Dependent
}

\author{
Amirulmukminin ${ }^{1}$ \\ 'Pascasarjana Universitas Negeri Surabaya, Indonesia \\ Email:mukmin_sorimandi@yahoo.com \\ DOI: http://dx.doi.org/10.15294/kreano.v8i2.7120 \\ Received : August 2016; Accepted: June 2017; Published: June 2017
}

\begin{abstract}
Abstrak
Penelitian ini bertujuan untuk mendeskripsikan kemampuan calon guru matematika dalam pengajuan masalah ditinjau dari gaya kognitif field independent (FI) dan field dependent (FD). Terdapat dua subjek dalam penelitian ini, yaitu mahasiswa calon guru Pendidikan Matematika semester VI, IKIP Mataram. Gaya kognitif subjek ditentukan berdasarkan skor pemberian instrument GEFT dan kemampuan pengajuan masalah diperoleh melalui TPM dan wawancara. SFI dan SFD masing-masing mengajukan 10 masalah dari informasi berbentuk grafik dan kalimat verbal. Secara umum, kemampuan SFI lebih bagus dibandingkan SFD yaitu: (1) SFI mengajukan 7 masalah sementara SFD hanya mengajukan 5 masalah yang berkaitan dengan aritmetika sosial, (2) SFI mampu mengajukan masalah yang memenuhi semua unsur sintaksis dan semantik, sementara masalah yang diajukan SFD dari informasi grafik hanya memuat 2 unsur sintaksis dan 2 unsur semantik dan dan masalah yang diajukan dari informasi kalimat verbal masing-masing memuat 2 unsur sintaksis dan 3 unsur semantik, (3) SFI mengajukan 5 masalah, sementara SFD hanya mengajukan 1 masalah yang memuat data baru, (4) SFI mengajukan 2 masalah yang tidak bisa diselesaikan karena rasa penasaran, sementara SFD mengajukan 5 masalah yang tidak dapat diselesaikan karena kesalahan pemilihan kata, dan (5) SFI mengajukan masalah yang termasuk kategori mudah, sedang, dan sulit, sementara masalah yang diajukan SFD hanya masuk kategori masalah mudah.
\end{abstract}

\begin{abstract}
This is descriptive research with qualitative approach which has purpose to describe the skill of preserve teacher in problem posing observed from cognitive style of field independent (FI) and field dependent (FD). The subjects are two the mathematic students in the sixth semester, IKIP Mataram. Cognitive style of each subject was determined by giving GEFT instrument and to know the skill of preserve mathematics teacher in posing problem was obtained through TPM and interview. SFI and SFD each posed ten problems from graph information and verbal sentence. SFI has better skill in problem posing than SFD: (1) SFI posed seven problems, while SFD only posed five problems related to arithmetic, (2) on SFI, all problems which were posed fulfilled all syntaxes and semantic elements which had been decided. While, the graph information of SFD could only posed the information which showed two syntaxes elements and two semantic elements, and each posed problems of verbal sentence information has two syntaxes elements and three semantic elements, (3) SFI pose five new data, while SFD could only show one problem which contained new data, (4) SFI posed two unsolved problems because of wondering, while SFD posed five unsolved problems because of choosing words error, and (5) SFI posed problems were included in each easy, middle and difficult category, while SFD only posed problem in easy category.
\end{abstract}

Keywords: Skill Analysis, Problem Posing, Cognitive Stlyle, Field Independent, Field Dependent

\section{PENDAHULUAN}

Guru masih menjadi salah satu sumber utama bagi pengetahuan siswa. Karena apa yang harus dilakukan siswa, tergantung perintah guru. Elwan (2000) menjelaskan, guru memi- liki peran besar, usaha siswa dalam memecahkan masalah, keberhasilan reformasi kurikulum dalam matematika pada akhirnya tetap kembali pada guru. Djamarah (2002) mempertegas, guru yang memberi stimulus, me- 
latih dan menentukan apa yang harus dilakukan siswa. Salah satu kemampuan yang harus dimiliki guru adalah kemampuan pengajuan masalah. Sebab keterampilan dan kemampuan guru dalam pengajuan masalah menjadi bagian penting dalam keberhasilan kegiatan belajar mengajar. Lavy \& Shriki (2007) menjelaskan kemampuan guru dalam pengajuan masalah dapat membantu siswa mengurangi ketergantungan pada buku teks dan memberikan perasaan lebih terlibat dalam kegiatan belajar. Jauh sebelumnya, Elwan (2000) menyarankan untuk menekan penggunaan buku teks, meningkatkan pengetahuan konten dan keterampilan dalam pengajuan masalah sehingga guru memiliki keyakinan menentukan arah pemecahan masalah secara kreatif.

Dewasa ini, pengajuan masalah menarik perhatian para ahli. Sebab, pengajuan masalah dapat menjadi pemicu berbagai kompetensi dalam diri. Banyak penelitian yang mengungkapkan kemampuan pengajuan masalah dapat mendorong kemampuan berpikir kritis, kreatif, terampil dan lain-lain, sehingga tepat untuk diterapkan di dalam kelas. Leung \& Chiayi (1997) mengungkap hubungan pengajuan masalah dan kreativitas. "menciptakan masalah" merupakan karakteristik pengajuan masalah dan "membuat menjadi" merupakan sifat kreativitas, sehingga dinilai bahwa pengajuan masalah merupakan bagian penting dari kreativitas. Hsiao, Hun, Lan, \& Jeng (2013) menjelaskan terdapat pengaruh positif dari pengajuan masalah pada pengetahuan konten, pemahaman, kemampuan analisis, keterampilan pemecahan masalah, dan keyakinan tentang materi pelajaran telah banyak dibuktikan. Arika dan Una (2014) menjelaskan pengajuan masalah memiliki peran penting untuk meningkatkan pemecahan masalah, mengembangkan keterampilan berpikir kreatif, karena pengajuan masalah memiliki potensi memicu kreativitas. Namun kenyataannya, tidak semua guru terampil dalam pengajuan masalah. Isik \& Kar (2012) mengatakan mayoritas pengajuan masalah calon guru terbukti lemah. Begitu juga dengan hasil penelitian Isik \& Kar (2012), masih ditemukan banyak kesulitan dan kesalahan calon guru dalam mengajukan masalah.

Mishra \& lyer (2013) mendefinisikan pengajuan masalah sebagai menggeneralisasi masalah baru atau pertanyaan berdasarkan situasi yang diberikan. Silver (1994), Ticha \& Hošpesová (2010), dan Isik \& Kar (2014) juga melihat pengajuan masalah sebagai menggeneralisasi masalah baru dan menformulasi masalah yang ada. Pada dasarnya, pengajuan masalah bagi Song, Yim, Shin \& Lee (2007) didefinisikan dalam berbagai cara yang berbeda, tetapi mengacu pada makna yang sama, seperti yang diungkapkan Kilpatrick (1987) menempatkan sebagai 'perumusan masalah', dan Silver (1994) menggambarkan sebagai 'generasi masalah', sementara Brown \& Walter (1990) menyebut sebagai 'pengajuan masalah'. Dalam penelitian ini, pengajuan masalah diartikan sebagai menciptakan atau mengajukan masalah baru dari informasi yang diberikan.

Silver (1994) membagi kegiatan pengajuan masalah dapat diaplikasikan dalam tiga bentuk aktivitas kognitif yaitu Pre-solution posing yaitu masalah yang diajukan berasal dari situasi atau stimulus yang diberikan, within-solution posing yaitu masalah diajukan ketika dalam memecahkan masalah dan post-solution posing yaitu masalah diajukan setelah menghasilkan dan dipecahkan kemudian diformulasi masalah baru. Sementara itu, Stoyanova \& Ellerton (1996) membagi kegiatan pengajuan masalah dalam tiga tipe yaitu, Pengajuan masalah bebas (free problem posing) yaitu masalah dihasilkan melalui situasi yang diberika dapat berupa situasi yang dibuat atau situasi asli. Beberapa arahan dapat diberikan untuk mendorong tindakan spesifik tertentu, pengajuan masalah semi struktur (semi-structured problem posing), yaitu berupa pemberian informasi terbuka dan meminta mengeksplorasi informasi tersebut dan menyelesaikan menggunakan pengetahuan, keterampilan, konsep dan berhubungan dengan pengalaman matematika sebelumnya. Pengajuan masalah terstruktur (structured problem posing) yaitu berupa pengajuan masalah didasarkan pada suatu masalah tertentu, dalam rangka mengungkapkan struktur kemampuan matematika. Pengajuan masalah dalam penelitian ini menggunakan tipe semi-structured problem posing, karena diharapkan calon guru dapat menggunakan pengetahuan, ke- 
terampilan, konsep dan berhubungan dengan pengalaman matematika yang dimiliki.

Banyak hal yang mempengaruhi kemampuan dalam pengajuan masalah, salah satunya gaya kognitif. Setiap individu memiliki cara yang berbeda-beda dalam melihat, berpikir, mengevaluasi dan menformulasi informasi yang diberikan sebagai acuan dalam mengajukan masalah. Karena gaya kognitif menurut Witkin (1972) sebagai model atau karakteristik yang berfungsi untuk mengungkapkan seluruh kegiatan persepsi dan aktivitas intelektual dengan cara yang sangat konsisten dan sangat meresap. Messick (1982) juga melihat gaya kognitif sebagai karakteristik yang stabil atau konsisten dalam berpersepsi, mengingat, berpikir dan memecahkan masalah. Karena dalam penelitian ini dilakukan untuk analisis kemampuan calon guru dalam mengajukan masalah dari informasi berkaitan dengan masalah aritmetika yang disajikan dalam bentuk grafik dan kalimat verbal, erat kaitannya dengan cara calon guru dalam melihat, dan menerima informasi tersebut, apakah informasi dilihat secara keseluruhan sehingga terpaku pada informasi tersebut atau mampu melihat secara spesifik sehingga memandang informasi lebih analitik. Karakteristik tersebut erat kaitan dengan gaya kognitif Field Independent (FI) dan Field Dependent (FD). FI merupakan individu dengan karakteristik condong melihat terpisah dari sejumlah pola dan menganalisis berdasarkan komponen, cenderung menciptakan struktur dengan sendiri, cenderung tidak terpengaruh dengan keadaan sekitar, dan tidak terlalu membutuhkan bantuan orang lain. Sementara FD merupakan individu dengan karakteristik tidak bisa memisahkan suatu kesatuan dan cenderung menerima bagian atau konteks yang dominan, cenderung melihat pola secara keseluruhan, lebih cenderung menciptakan struktur dengan bergantung bantuan orang lain.

Beberapa aspek yang ditetapkan untuk melihat kemampuan pengajuan masalah calon guru mengacu pada Silver dan Cai (1996), bahwa kemampuan pengajuan masalah dapat diketahui dari struktur bahasa yang dibagi menjadi unsur sintaksis dan semantik. Unsur sintaksis dibagi menjadi tiga, yaitu masalah yang diajukan menunjukkan suruhan beru- pa penugasan, hubungan dan pengandaian. Sementara aspek semantik berupa masalah yang diajukan mengandung menyatakan kembali, mengubah, membandingkan, mengelompok-kan dan menvariasikan. Selain itu, Silver dan Cai (1996) juga menegaskan kualitas masalah dapat dilihat dari ada tidak penyelesaiannya. Selain itu, Siswono (1999) juga menjelaskan terdapat beberapa aspek untuk melihat kemampuan pengajuan masalah yaitu, kesesuaian masalah dengan informasi, ada tidaknya penyelesaian dari masalah yang diajukan, jawaban atas masalah, struktur kalimat masalah dan tingkat kesulitas masalah. Rahma (2013) juga menambahkan aspek ada tidaknya data baru di dalam masalah yang diajukan.

Namun penelitian ini tidak menekankan pada kemampuan menyelesaikan masalah, hanya dianalisis dari masalah yang diajukan. Maka terdapat lima aspek untuk melihat kemampuan pengajuan masalah dalam penelitian ini yaitu: (1) Keterkaitan Masalah dengan Informasi. Dikatakan sesuai dengan informasi jika masalah yang diajukan masih berkaitan dengan informasi; (2) Struktur Bahasa, termasuk didalamnya adalah Sintaksis dan Semantik; (3) Ada tidaknya data baru. Data baru yang dimaksud adalah, data yang belum ada di dalam informasi namun tetap berkaitan dengan informasi; dan (4) Dapat Tidaknya Masalah Dipecahkan. Masalah dikatakan dapat dipecahkan jika memiliki data yang cukup, informasi dan perintah disampaikan dengan jelas; serta (5) Tingkat Kesulitan Masalah yang Diajukan.

Dari kelima tersebut di atas, dijelaskan lebih rinci sebagai beikut. Pada bagian Sintaksis, dibagi menjadi tiga yaitu masalah yang diajukan menunjukkan suruhan berupa penugasan, hubungan dan pengandaian, yaitu: Penugasan diartikan sebagai pertanyaan (masalah) yang menunjukkan tugas untuk dikerjakan; Hubungan diartikan sebagai pertanyaan (masalah) yang menunjukkan tugas berupa membandingkan; Pengandaian diartikan sebagai pertanyaan (masalah) yang menggunakan informasi tambahan.

Sedangkan semantik dibagi menjadi lima yaitu masalah yang diajukan mengandung menyatakan unsur kembali, mengubah, 
mengelompokkan, membandingkan, dan memvariasikan. Yang dijelaskan sebagai berikut: Menyatakan kembali, yaitu data yang ada di dalam masalah masih menggunakan data pada informasi; Mengubah, yaitu masalah yang diajukan menggunakan data yang berbeda dengan informasi; Membandingkan, yaitu masalah yang diajukan mengandung unsur pembanding untuk mengetahui persamaan atau selisih; Mengelompokkan, yaitu masalah yang diajukan menggunakan beberapa data di dalam satu masalah, baik data yang ada di dalam informasi maupun menggunakan data baru; Memvariasikan, yaitu masalah yang diajukan menggabungkan data yang sudah ada dan data baru.

Pada tingkat kesulitan masalah dibagi dalam tiga kategori, yaitu: (1) Mudah, jika masalah diselesaikan cukup menggunakan data di dalam informasi; (2) Sedang, jika masalah diselesaikan tidak hanya menggunakan data pada informasi, tetapi juga perlu dilakukan perhitungan atau diolah terlebih dahulu; (3) Sulit, jika masalah diselesaikan tidak hanya menggunakan data pada informasi, tetapi perlu diolah terlebih dahulu lebih dari satu prosedur.

\section{METODE}

Penelitian ini merupakan penelitian deskriptif dengan pendekatan kualitatif, yaitu mendeskripsikan kemampuan calon guru matematika yang memiliki gaya kognitif Field Independent (FI) dan Field Dependent (FI). Subjek dalam penelitian ini adalah mahasiswa semester VI Pendidikan Matematika IKIP Mataram yang merupakan calon guru matematika.

Instrument dalam penelitian ini terdiri dari peneliti sebagai instrument utama, karena peneliti secara langsung melakukan wawancara secara mendalam untuk mendapat informasi tentang kemampuan pengajuan masalah calon guru dan Instrumen Pendukung yang terdiri dari Group Embedded Figures Test (GEFT), Tes Pengajuan Masalah (TPM) dan pedoman wawancara. GEFT digunakan untuk menentukan subjek yang bergaya kognitif FI dan FD. TPM digunakan untuk menggali kemampuan pengajuan masalah calon guru matematika dan pada TPM tersebut diberikan informasi dalam bentuk grafik dan kalimat verbal, kemudian dipertajam melalui kegiatan wawancara.

Analisis data dilakukan dalam 3 tahap yaitu, pertama reduksi data dimaksudkan untuk merangkum data, memilih dan menfokuskan pada hal pokok, menyederhanakan dan mentransformasi data mentah sesuai kebutuhan penelitian. Kedua, penyajian data berupa mengklasifikasi dan mengindentifikasi data yaitu menuliskan kumpulan data yang telah dikelompokkan sehingga memungkinkan untuk dilakukan penarikan kesimpulan. Ketiga, Penarikan kesimpulan didasarkan pada hasil analisis data yang terkumpul, baik diperoleh dari jawaban tertulis maupun hasil wawancara.

\section{HASIL DAN PEMBAHASAN}

\section{Informasi Grafik}

Berikut ini paparan hasil dan pembahasan kemampuan pengajuan masalah calon guru matematika dari informasi grafik.

\section{Keterkaitan Masalah Dengan Informasi}

Ke dua subjek mampu mengajukan masalah sesuai informasi yang diberikan. Hanya saja, SFD tidak mampu mengajukan masalah yang berkaitan dengan masalah aritmetika. Berbeda dengan SFI yang mampu mengajukan dua masalah yang berkaitan dengan aritmeitka sosial.

\section{Struktur Bahasa}

Semua masalah yang diajukan SFI mewakili semua unsur sintaksis dan semantik. Namun berbeda dengan SFD, masalah yang diajukan hanya mengandung 2 unsur sintaksis yaitu suruhan yang berupa penugasan dan hubungan. Sementara struktur semantik hanya mengandung menyatakan kembali dan mengelompokkan saja.

\section{Termuat Tidaknya Data Baru}

Terdapat 2 masalah yang diajukan SFI mengandung data baru, yaitu data tambahan yang tidak ada dalam informasi grafik. Sementara SFD tidak mengajukan data baru.

Dapat Tidaknya Masalah Dipecahkan 
Dari 5 masalah yang diajukan SFI, terdapat dua masalah yang tidak dapat dipecahkan. Hal itu karena terdapat 2 masalah yang termasuk masalah non matematika. Sementara masalah yang diajukan SFD hanya satu yang dapat diselesaikan. Tidak bisa diselesaikan masalah tersebut karena kesalahan SFD dalam memilih bahasa yang tepat untuk mewakili maksudnya sendiri.

\section{Tingkat Kesulitan Masalah}

Dilihat dari masalah yang diajukan SFI, termasuk masalah dengan kategori mudah, sedang dan sulit. Karena untuk menyelesaikan masalah-masalah tersebut, tidak hanya menggunakan data yang ada pada informasi, tapi juga membutuhkan pengelolaan data terlebih dahulu. Sementara masalah yang diajukan SFD hanya termasuk kategori mudah saja.

\section{Informasi Kalimat Verbal}

Berikut ini hasil dan paparan kemampuan calon guru matematika dalam mengajukkan masalah dari informasi kalimat verbal.

\section{Keterkaitan Masalah dengan Informasi}

Semua masalah yang diajukan SFI dan SFD berkaitan dengan masalah informasi dan masalah aritmetika sosial.

\section{Struktur Bahasa}

Masalah yang diajukan SFI memenuhi semua struktur sintaksis dan semantik. Berbeda dengan masalah yang diajukan SFD, dari struktur sintaksis hanya memuat suruhan berupa menyatakan penugasan dan pengandaian. Sementara struktur semantik hanya berupa menyatakan kembali, mengubah dan mengelompokkan.

\section{Termuat Tidaknya Data Baru}

Dari pengajuan masalah oleh SFI, terdapat 3 masalah yang memuat data baru. Sementara masalah yang diajukan SFD hanya 1 masalah yang memuat data baru.

\section{Dapat Tidaknya Masalah Dipecahkan}

Semua masalah yang diajukan SFI memiliki penyelesaian. Sementara masalah yang diajukan SFD lagi-lagi ada beberapa masalah yang tidak bisa diselesaikan, hal itu disebabkan karena pemilihan kata yang tidak tepat untuk mencerminkan keinginannya sendiri. Masalah baru memiliki penyelesaian ketika dikonfirmasi dan diperbaiki pada kegiatan wawancara.

\section{Tingkat Kesulitan Masalah}

Tingkat kesulitan masalah yang diajukan SFI termasuk kategori mudah, sedang dan sulit. Sebab untuk menyelesaikan masalah tersebut bisa menggunakan data pada informasi, sementara beberapa masalah yang lain perlu diolah terlebih dahulu baru bisa diselesaikan. Berbeda dengan masalah yang diajukan SFD hanya termasuk kategori mudah.

Selain 5 aspek tersebut, terdapat beberapa aspek lain dalam pengajuan masalah yang telah diungkapkan Silver dan Cai (1996), yaitu masalah yang diajukan dapat berupa pernyataan, pertanyaan matematika dan pertanyaan non matematika. Pada penelitian ini, ditemukan SFI mengajukan masalah dengan tipe masalah non matematika. SFD juga mengajukan masalah yang hampir sama, yaitu masalah tipe non matematika. Hal itu sebabkan karena kesalahan dalam memilih kata untuk menyusun masalah, seperti penggunaan kata "bagaimana" yang seharusnya "berapa". Padahal menurut Siswono (1999), penggunaan bahasa yang jelas dan tepat menjadi salah satu tolak ukur masalah diajukan atas dasar proses berpikir atau hanya asal mengajukan saja.

Sebelum SFI mengajukan masalah, terlebih dahulu mencari penyelesaiannya. Karena sebelum masalah diajukan, SFI memastikan masalah tersebut memiliki penyelesaian. Berbeda dengan SFD, tidak memperkirakan dan mengabaikan seperti apa penyelesaian dari masalah tersebut. SFD mengajukan masalah hanya berdasarkan data pada informasi saja. SFD baru mengetahui jawaban ketika dikonfirmasi pada kegiatan wawancara. Terbukti ketika diminta untuk menjelaskan cara menyelesaikan salah satu masalah, SFD malah 
kebingungan dan tidak bisa menjelaskannya. PENUTUP

\section{Simpulan}

Semua masalah yang diajukan SFI mengacu pada informasi yang diberikan. Namun hanya 2 masalah yang berkaitan dengan aritmetika sosial, sementara semua masalah yang diajukan dari kalimat verbal berkaitan dengan aritmetika sosial. Dari aspek struktur bahasa, SFI mampu mengajukan masalah yang memuat semua unsur sintaksis yaitu yang menunjukkan suruhan berupa penugasan, hubungan dan pengandaian. Begitu juga dengan struktur semantik, kelima unsur semantik. SFI mampu mengajukan soal yang memuat data baru, yaitu terdapat 2 masalah pada informasi grafik dan terdapat 3 masalah pada informasi kalimat verbal. Hanya saja, tidak semua masalah yang diajukan dari informasi grafik dapat diselesaikan karena termasuk kategori non matematika. Sementara masalah dari informasi kalimat verbal semuanya memiliki penyelesaian. Masalah yang diajukan SFI termasuk masalah yang mudah, sedang dan sulit.

Walaupun masalah yang diajukan SFD menggunakan data pada informasi yang diberikan, namun masalah yang diajukan dari informasi berbentuk grafik tidak satupun berkaitan dengan aritmetika sosial. Berbeda dengan masalah yang diajukan dari informasi berbentuk kalimat verbal, semua masalah tersebut berkaitan dengan aritmetika sosial. Pada informasi grafik, SFD hanya mampu mengajukan masalah yang menunjukkan dua unsur pada sintaksis yaitu penugasan dan hubungan, sementara pada semantik, hanya berupa menyatakan kembali dan mengelompokkan. Sementara pada informasi kalimat verbal, hanya memuat dua unsur pada sintaksis yaitu penugasan dan pengandaian, sementara pada semantik hanya berupa menyatakan kembali, mengubah, dan mengelompokkan. Hanya 1 masalah yang diajukan SFD yang memuat data baru, yaitu masalah yang diajukan dari informasi kalimat verbal. Hanya satu masalah yang diajukan dari informasi grafik yang memiliki penyelesaian, sementara empat masalah lain terdapat kesalahan dalam pemilihan kata dan data yang diajukan tidak lengkap. Sementara masalah yang diajukan dari informasi kalimat verbal, terdapat satu masalah yang tidak dapat diselesaikan, karena penggunaan kata yang tidak tepat. SFD hanya mampu mengajukan masalah dengan kategori mudah.

\section{Saran}

Berdasarkan hasil penelitian, beberapa saran yang dapat peneliti kemukana di antara lain: (1) Penelitian ini hanya menfokuskan pada kemampuan calon guru dalam pengajuan masalah, tidak terlalu memperhatikan seperti apa proses berpikir calon guru dalam mengajukan masalah. Padahal lebih bagus jika analisis dilakukan dengan menekankan pada proses sekaligus pada hasil atau masalah yang diajukan, sehingga data yang disajikan lebih akurat dan lengkap; (2) Kemampuan pengajuan masalah pada dasarnya tidak hanya dapat dinilai dari kualitas masalah yang diajukan, namun perlu juga diperhatikan apakah subjek dapat menyelesaikan atau tidak. Hal itu untuk mengetahui apakah calon guru mengajukan masalah tersebut berdasarkan pemahaman dan pengetahui atau hanya coba-coba saja; (3) Kajian pada penelitian ini terbatas pada kemampuan pengajuan masalah berdasarkan gaya kognitif saja, tidak berdasarakan tingkat kemampuan matematika. Untuk memperkaya tinjauan penelitian diharapkan dapat dilakukan penelitian lanjutan dengan memperhatikan menambah subjek penelitian dengan memperhatikan tingkat kemampuan matematika.

\section{DAFTAR PUSTAKA}

Arikan, E.E. \& Unal, H. (2014). Development of the structured problem posing skills and using metaphoric perceptions. European Journal of Science and Mathematics Education, 2(3), 155-166.

Djamarah, S. B. (2002). Psikologi Belajara. Jakarta: PT Rineka Cipta

Elwan, A.R. (2000). The development of Mathematical Problem Posing Skills for Prospective Middle School Teachers. Mathematics Education, Sultan Qaboos University, Muscat, Sultant of Oman. 
Hsiao, J.Y., Hung, C.L., Lan, Y.F. \& Jeng, Y.C. (2013) . Integrating Worked Examples Into Problem Posing In A Web-Based Learning Environment. The Turkish Online Journal of Educational Technology, 12(2)

Isik, C. \& Kar, T. (2012) The Analysis of the Problems the Pre-Service Teachers Experience in Posing Problems about Equations. Australian Journal ofTeacher Education, 37(9), Article 6.

Isik, C. \& Kar, T. (2014). Analysis of Problems Posed by Pre-service Primary Teachers about Adding Fractions in terms of Semantic Structures. International Society of Educational Research, 9(2), 135-146.

Lavy, I. \& Shriki, A. (2007). Problem Posing As A Means For Developing Mathematical Knowledge Of Prospective Teachers. Proceeding of the 31th Conference of the international Group for the Psychology of Mathematics Education (PME), 3, 129-136.

Leung, S. K., \& Chiayi (1997). On the Role of Creative Thinking in Problem Posing. Chiayi (Taiwan).

Messick, S. (1982). Cognitive Styles In Educational Practice. Research Report. Paper presented at the annual meeting of the American Educational Research Association, New York, 1982.

Mishra, S. \& Iyer, S. (2013). Problem Posing Exercises (PPE): An instructional strategy for learning of complex material in introductory programming courses. IEEE International Conference on Technology for Education ( $T_{4} E$ ). Kharagpur, India, December 2013.

Rahman, A. (2013). Pengajuan Masalah Matematika Ditinjau Dari Gaya Kog- nitif Dan Kategori Informasi. Jurnal Ilmu Pendidikan, 19(2), 244-251.

Silver, E. A. (1994). On mathematical problem posing. For the learning of mathematics, 14(1), 19-28.

Silver, E.A., \& Cai, J. (1996). An Analysis of Arithmetic problem Posing by Middle School Students. Journal for research in Mathematics Education, 27(5), 521-539.

Siswono, T.Y.E. (1999). Metode Pemberian Tugas Pengajuan Soal (Problem Posing) dalam Pembelajaran Matematika Pokok Bahasan Perbandingan di MTs Negeri Rungkut Surabaya (Tesis magister pendidikan matematika tidak dipublikasikan). Universitas Negeri Surabaya.

Song, S.H., Yim, J.H., Shin, E.J. \& Lee, H.H. (2007). Posing Problems With Use The 'What If Not?' Strategy In Nim Game. Proceedings of the $31^{\text {st }}$ Conference of the International Group for the Psychology of Mathematics Education, 4, 193-200.

Stoyanova, E. \& Ellerton, N.F. (1996). A Framework for Research into student's problems posing in School mathematics. Technology in Mathematics Education, 518-525.

Ticha, M. \& Hospesova, A. (2010). Problem Posing And Development of Pedagogical Content Knowledge In Pre-Service Teacher Training. Proceedings of CERME 6 January $28^{\text {th }}$ February $1^{\text {st }} 2010$.

Witkin, H.A. (1973). The Role of Cognitive Style in Academic Performance and in Teacher-Student Relations. Research Bulletin. 1973, 73-11, Princeton, N. J. Educational Testing Service. 